\title{
'TAQUARI', A NEW AND A PROMISING MANGO MATERIAL: EMERGENCE, POST-HARVEST AND BIOMETRICS OF FRUIT
}

\author{
'TAQUARI': UM NOVO E PROMISSOR MATERIAL DE MANGUEIRA
}

\section{Guilherme NACATA ${ }^{1}$; Renata Aparecida de ANDRADE ${ }^{2}$, Kelly Magalhães MARQUES ${ }^{3}$, Ariadne Kaleda MARINO ${ }^{4}$; Ben-Hur MATTIUZ ${ }^{2}$}

1. Aluno de Doutorado em Agronomia (Fitotecnia), Universidade de São Paulo, Escola Superior de Agricultura "Luís de Queiroz", Piracicaba, SP, Brazil. guilhermenacata@usp.br; 2. Professor (a) Universidade Estadual Paulista, FCAV-Jaboticabal, SP, Brazil; 3. Professora do Centro Universitário Moura Lacerda, CUMI, Ribeirão Preto, SP, Brazi; 4. Aluna de Mestrado em Agronomia (Produção Vegetal), Universidade Estadual Paulista, FCAV-Jaboticabal, SP, Brazil.

\begin{abstract}
The fruit of 'Taquari' have attractive appearance, with intense yellow flesh, pleasant taste and absence of fibers, which makes it a potential material for, after a series of studies, being released as a variety. For biometrics, 50 mature fruit were used the results (average of three samples) were evaluated by descriptive statistics using central trend (average) and variability of data (standard error and coefficient of variation). For the germination test, the seeds were extracted from ripe fruit and dried; subsequently, they were germinated in sachets containing the mixture soil:sand:corral manure $(3: 1: 1)$ as substrate, evaluating seedling emergence and polyembryony. The design was in randomized blocks and 5 treatments were studied, with 5 replicates each and 10 seeds per replicate. The percentage data were transformed into arc-sen, submitted to analysis of variance and the means, to Tukey test at 5\% probability. For fruit quality characterization, 12 ripe fruits were used, separated into 3 lots with 4 fruit, using a completely randomized design. The fruit were characterized regarding firmness, peel and pulp color, soluble solids, titratable acidity, $\mathrm{pH}$, ascorbic acid and respiratory rate. We conclude that the 'Taquari' has fruit with interesting characteristics for the Brazilian market and there is a better seedling emergence in the absence of seed coat, but with a greater occurrence of polyembryony. For quality characterization, the fruit present parameters such as soluble solids and titratable acidity similar to the main varieties of mangoes sold in the country, but with emphasis to the high ascorbic acid content detected.
\end{abstract}

KEYWORDS: Chemical characterization. Mangifera indica L. Polyembryony. Propagation.

\section{INTRODUCTION}

Mango (Mangifera indica L.), which belongs to the family Anacardiaceae, is among the tropical fruits with the highest economic expression in the Brazilian and International markets (1.132.463 tons), not only for being exotic in terms of appearance and flavor, but also for being a rich source of carotenoids and carbohydrates (SIVANKALYANI et al., 2016; FAO, 2017).

Among the cultivars with commercial importance, 'Tommy Atkins', with 48,025 tons in 2014 is the most cultivated and exported in the country because of its good productivity, ability to adapt to different cultivation environments, higher tolerance to certain diseases, besides presenting fruit with quality and good post-harvest conservation (AGRIANUAL, 2017).

Seed germination is regarded as the resumption of growth from the embryonic axis, which is paralyzed at the final stages of the maturation process, but develops when stimulated by environmental conditions, then occurring coat rupture by the radicle. It is a critical step of the plant biocycle, because of its association with several factors of extrinsic nature, such as environmental factors, and intrinsic nature, related to physiometabolic factors. (HARTMANN et al., 2010).

The morphologic characterization of the plant provides an identity for each material by the use of descriptors that enable the study of the genetic variability; therefore, these characters guarantee a signature of plant species identity, as well as varietal and genetic purity, also being used for many researchers for germplasm characterization and, although there are more advanced techniques, the techniques for morphological characterization are more accessible and anticipate other techniques, thus making it possible to direct the work to be developed with more sophisticated descriptors, such as molecular markers (GUSMÃO et al., 2016).

Thus, the biometric characterization of fruits can be used as an indicative of the genetic variability to be explored in breeding programs, providing important information, thus allowing the differentiation of species of the same Genus, determining their conditions of weight, width, length, diameter, volume, being consolidated as a tool for fruit classification, with importance for taxonomy, in the identification of varieties and to 
verify the occurrence of phenotypic variations (SOUZA et al., 2017).

In fruit maturation, in general, there are transformations which reflect in changes in their quality characteristics (BURDON et al., 2017), such as color, texture, flavor, aroma, soluble solids content, titrable acidity, $\mathrm{pH}$, respiratory activity, among others, which indicate maturation and further senescence.

Fruit quality cannot be measured only by the physical characteristics, such as size and weight, since not always the fruits with good appearance present organoleptic attributes and desirable yields for the market, with good conservation during storage. Therefore, it is necessary that the fruits be evaluated regarding quality characteristics, aiming at granting the best post-harvest conservation and meeting consumers' demands (ZUFFO et al., 2016)

Facing the importance of the mango culture and the possibility of emergence of a new material, this work aimed to evaluate seed germination by seedling emergence, in the presence and absence of coat, besides performing the biometric characterization of fruit and seeds of the 'Taquari' fruit tree, as well as performing the physical and quality characterization of the fruit, allowing a broader knowledge and comparison with the most traditional and most cultivated cultivars.

\section{MATERIAL AND METHODS}

\section{Biometric characterization}

For the biometric characterization, 50 ripe fruit were used, collected from an adult plant of 'Taquari' fruit (material originated from the seed, without data on the parental plants) and the following were obtained: masses from fruit, peel, kernel and seed (grams, in a digital scale with precision of $0.001 \mathrm{~g}$ ); length and width of fruit, kernel and seed $(\mathrm{cm}$, with the aid of a graduated ruler, measuring the width in the central part and considering as length the distance between the basal and apical portions); and pulp percentage. The results (average of three samples) were evaluated by descriptive statistics using central trend (average) and variability of data (standard error and coefficient of variation). The number of classes for each parameter evaluated was determined, the amplitude of the data was calculated, as well as the length of each interval of class, determining the superior and inferior limits. Tables of frequency were used to organize the data, then correlating the classes of values and the frequency of the number of values that fit into each class. For all characters evaluated, three classes were determined, namely, for mass: light, medium and heavy; for length: short, medium and long; for width: narrow, medium and large; and for pulp percentage: low, medium and high.

\section{Germination test}

For the germination test, the seeds (with coat) were extracted from ripe fruit, washed, dried in the shadow and, to germinate, placed in polyethylene sachets with capacity for 1.5 liters, containing as substrate a mixture of soil + sand + corral manure, in the proportion 3:1:1. For the treatment without coat, after drying the kernel, it was carefully removed with the use of pruning shears. The following characters were evaluated: a) seedling emergence (for 12 weeks), in percentage; and b) polyembryony (for nine weeks, starting on the fourth week after emergence). The design was in randomized blocks, using five repetitions with 10 seeds for each treatment. For the emergence, the percentage data were transformed into arc-sen and subjected to the analysis of variance and the means, to the Tukey test at $\mathrm{p}>0.05$ probability. For polyembryony, the data were analyzed establishing the confidence interval by the $\mathrm{t}$ test at 5\% probability. The interval was determined using the equation: $I C=(t \mathrm{x}$ desvpad $) / \mathrm{raizn} r$, in which $I C=$ confidence interval; $t=$ tabulated $t$ value, $\mathrm{p}>0.05$ probability; desvipad = standard deviation; and raiz $n r=$ square root of the number of repetitions.

\section{Physical and quality characterization}

For the physical and quality characterization of the fruit, 12 ripe fruits were used, separated into 3 lots with 4 fruit, collected from an adult plant of the 'Taquari'. They were washed with neutral detergent, washed in running water and sanitized in Sumaveg ${ }^{\circledR}$ solution (Active principle: Sodium Dichloroisocyanurate Dihydrate, Active Chlorine Content $=3 \%$ minimum) at $200 \mathrm{mg} \mathrm{L}^{-1}$ of free chlorine, for 5 minutes.

After dried at room temperature, they were selected based on coloration, size and absence of defects and symptoms of disease, and analyzed according to the following parameters: fruit respiratory rate $\left(\mathrm{ml} \mathrm{CO}_{2} \mathrm{~kg}^{-1} \mathrm{~h}^{-1}\right)$ in a chromatograph of the model Trace GC Ultra, Thermo Scientific; fruit fresh mass, expressed in grams, quantified in a scale with precision of $0.01 \mathrm{~g}$, pulp firmness, in Newtons, determined at the equatorial region of the fruit after peel removal, using a penetrometer of the brand Digital Force Gauce, model: IP-200 with tip of $8 \mathrm{~mm}$; peel and pulp coloration, using a colorimeter MINOLTA CR 400, brand KONICA MINOLTA, where the values of $L^{*}, h^{*}$ and $C^{*}$ were 
determined, with $\mathrm{L}^{*}$ representing: luminosity $(100=$ white; $0=$ black), $\mathrm{h}^{*}$ : Hue Angle and $\mathrm{C}^{*}$ : chromaticity (Minolta, 2007); titrable acidity of the fruit, determined in 10 grams of ground pulp, diluted in $50 \mathrm{~mL}$ of distilled water, by titration with $0.1 \mathrm{M} \mathrm{NaOH}$; for the quantification, the methodology described by AOAC was employed (1997); soluble solids contents of the fruit according to AOAC (1997), from the ground fruit pulp, using gauze to obtain the liquid, and quantified in a digital refractometer of the model PR 101, with the results expressed in ${ }^{\circ} \mathrm{Brix}$; fruit $\mathrm{pH}$, determined using a $\mathrm{pH}$ meter of the model Tec-3MP, based on the technique of AOAC (1997), and ascorbic acid content, determined as indicated by AOAC (1997) from $10 \mathrm{~g}$ of ground pulp, and the results were expressed in mg ascorbic acid $\mathrm{g}^{-1}$ of pulp.

\section{RESULTS AND DISCUSSION}

\section{Biometric characterization}

Based on the biometry, the fruit can be classified as long (Table 1) (12.86 to $13.90 \mathrm{~cm}$ ), with medium width (Table 2) of 6.3 to $7.1 \mathrm{~cm}$, peel mass (Table 3) between 20.41 and 30.76 grams and medium pulp percentage (Table 4 ) of 70.16 to $76.45 \%$, resulting in a total mass (Table 5) between 203.33 and 241.66 grams.

Table 1. Length class of the 'Taquari', considering fruit percentage in each frequency interval.

\begin{tabular}{lll}
\hline Fruit length class & Frequency interval $(\mathbf{c m})$ & \% of fruit \\
\hline Short & 10.80 to 11.83 & 32 \\
Medium & 11.83 to 12.86 & 28 \\
Long & 12.86 to 13.90 & 40 \\
\hline Standard deviation & 0.87 & \\
\hline
\end{tabular}

Table 2. Width class of 'Taquari', considering the percentage of fruit in each frequency interval.

\begin{tabular}{lll}
\hline Fruit width class & Frequency interval $(\mathbf{c m})$ & \% of fruit \\
\hline Narrow & 5.5 to 6.3 & 24 \\
Medium & 6.3 to 7.1 & 56 \\
Large & 7.1 to 7.9 & 20 \\
\hline Standard deviation & 0.53 & \\
\hline
\end{tabular}

Table 3. Peel mass class of 'Taquari', considering the percentage of fruit in each frequency interval.

\begin{tabular}{lll}
\hline Peel mass class & Frequency interval (grams) & \% of fruit \\
\hline Light & 10.06 to 20.41 & 12 \\
Medium & 20.41 to 30.76 & 64 \\
Heavy & 30.76 to 41.1 & 24 \\
\hline Standard deviation & 5.62 & \\
\hline
\end{tabular}

Table 4. Pulp percentage class of 'Taquari', considering the percentage of fruit in each frequency interval.

\begin{tabular}{lll}
\hline Pulp percentage class & Frequency interval (\%) & \% of fruit \\
\hline Low & 63.87 to 70.16 & 14 \\
Medium & 70.16 to 76.45 & 72 \\
High & 76.45 to 82.74 & 14 \\
\hline Standard deviation & 3.34 & \\
\hline
\end{tabular}

Table 5. Mass class of 'Taquari', considering the percentage of fruit in each frequency interval.

\begin{tabular}{lll}
\hline Fruit mass class & Frequency interval (grams) & \% of fruit \\
\hline Light & 165.00 to 203.33 & 26 \\
Medium & 203.33 to 241.66 & 58 \\
Heavy & 241.66 to 280.00 & 16 \\
\hline Standard deviation & 23.73 & \\
\hline
\end{tabular}


Around $60 \%$ of the kernels have length (Table 6) between 9.3 and $10.4 \mathrm{~cm}$ and width (Table 7) between 3.1 and $3.4 \mathrm{~cm}$, with mass (Table 8) between 27.60 and 34.14 grams. Regarding the seeds, they can be considered long (Table 9) (7.34 to $8.00 \mathrm{~cm}$ ), with width (Table10) between 2.5 and $3.0 \mathrm{~cm}$ and mass (Table 11) between 17.14 and 21.21 grams.

Table 6. Length class of 'Taquari', kernel, considering the percentage of fruit in each frequency interval.

\begin{tabular}{lll}
\hline Kernel length class & Frequency interval $(\mathbf{c m})$ & \% of fruit \\
\hline Short & 8.2 to 9.3 & 34 \\
Medium & 9.3 to 10.4 & 60 \\
Long & 10.4 to 11.5 & 6 \\
\hline Standard deviation & 0.59 & \\
\hline
\end{tabular}

Table 7. Width class of 'Taquari' kernel, considering the percentage of fruit in each frequency interval.

\begin{tabular}{lll}
\hline Kernel width class & Frequency interval $(\mathbf{c m})$ & \% of fruit \\
\hline Narrow & 2.8 to 3.1 & 26 \\
Medium & 3.1 to 3.4 & 40 \\
Large & 3.4 to 3.7 & 34 \\
\hline Standard deviation & 0.21 & \\
\hline
\end{tabular}

Table 8. Mass class of 'Taquari' kernel, considering the percentage of fruit in each frequency interval.

\begin{tabular}{lll}
\hline Kernel mass class & Frequency interval (grams) & \% of fruit \\
\hline Light & 21.06 to 27.60 & 20 \\
Medium & 27.60 to 34.14 & 70 \\
Heavy & 34.14 to 40.68 & 10 \\
\hline Standard deviation & 3.58 & \\
\hline
\end{tabular}

Table 9. Seed length class of 'Taquari', considering the percentage of fruit in each frequency interval.

\begin{tabular}{lll}
\hline Seed length class & Frequency interval $(\mathbf{c m})$ & \% of fruit \\
\hline Short & 6.00 to 6.67 & 22 \\
Medium & 6.67 to 7.34 & 36 \\
Long & 7.34 to 8.00 & 42 \\
\hline Standard deviation & 0.52 & \\
\hline
\end{tabular}

Table 10. Seed width class of 'Taquari', considering the percentage of fruit in each frequency interval.

\begin{tabular}{lll}
\hline Seed width class & Frequency interval $(\mathbf{c m})$ & \% of fruit \\
\hline Narrow & 2.0 to 2.5 & 12 \\
Medium & 2.5 to 3.0 & 70 \\
Large & 3.0 to 3.5 & 18 \\
\hline Standard deviation & 0.35 & \\
\hline
\end{tabular}

Table 11. Seed mass class of 'Taquari', considering the percentage of fruit in each frequency interval.

\begin{tabular}{lll}
\hline Seed mass class & Frequency interval (grams) & \% of fruit \\
\hline Light & 13.07 to 17.14 & 16 \\
Medium & 17.14 to 21.21 & 54 \\
Heavy & 21.21 to 25.29 & 30 \\
\hline Standard deviation & 2.65 & \\
\hline
\end{tabular}

When the ratio of the values of fruit length and width is calculated, it can be noticed that the values range from 1.76 to 1.96 , evidencing the elongated shape. Fruit mass values for 'Taquari' were lower than those observed for the fruit of 'Palmer' (500g), 'Haden' (350g - 680g) and 'Tommy Atkins' (460g), varying between 165 and
280 grams in this study, which can be interesting for the market, since, according to the Brazilian Packaging Association (2015), the search for packages with smaller fruits and individual or fractional portions has risen considerably in the last years, which is due to the structuring of the Brazilian adult, of whom, according to the research, 
$30 \%$ live alone or as a couple without children (JAIME et al., 2015) and, although the fruit are smaller, pulp percentage is high - even in fruit classified as having a low pulp percentage presented more than $63 \%$ and the fruit with the highest expression, with more than $82 \%$ of pulp, an extremely positive characteristic.

Several works have been performed with biometrics of fruit trees, allowing the characterization and distinction of materials, using morphological characters, such as in breadfruit (Artocarpus altilis) (BEZERRA et al., 2017), taperebazeiro (Spondias mombin L.) (BAIA et al.,
2015), porangaba (COSSA et al., 2016), buriti (Mauritia fexuosa L. f.) (MATOS et al., 2014) and cocoa (Theobroma cacao) (VENIAL et al., 2017), which evidences the importance of this kind of marker in fruticulture, allowing a better characterization of fruits with possibility of market.

\section{Germination test}

Regarding germination, measured by the emergence of seedlings, it is observed, in Figure 1, that regardless of the treatment, it started on the third week of sowing.

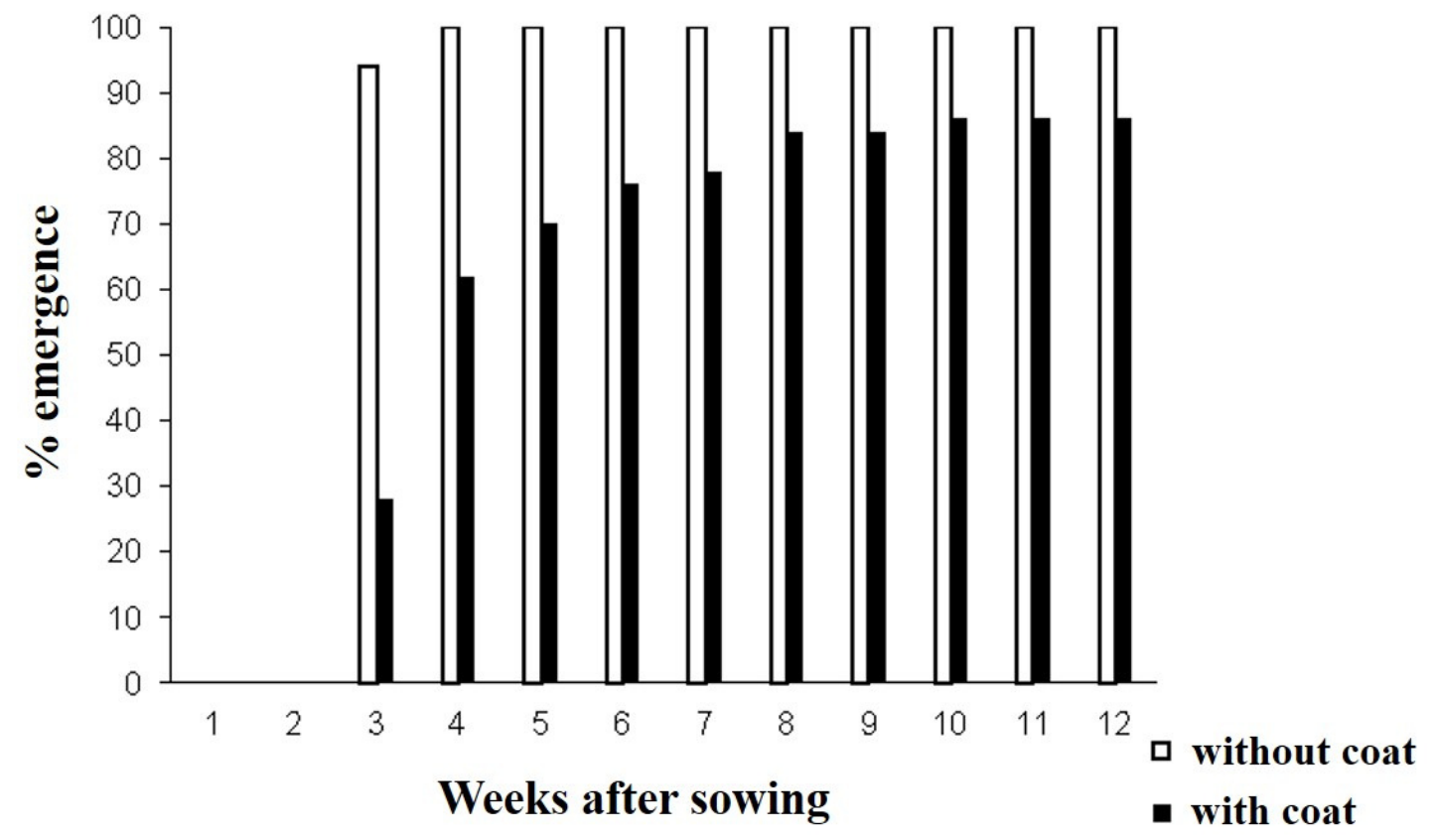

Figure 1. Percentage of emergence of 'Taquari' seedlings, with and without coat covering the seed.

For the treatment without coat on the seed, a higher precocity is noted, with $100 \%$ of emergence already on the fourth week after sowing, whereas for the treatment with coat, there were $86 \%$ de of emergence only on the ninth week, which is not interesting for the producer, increasing the costs with seedling in the nursery.

Some studies show that the coat, besides having a protective function to the embryo, presents some other purposes, such as: keeping the cotyledons together; acting as a barrier for fungi, insects and microorganisms; regulating the speed of seed rehydration, gas exchanges and seed germination and, in some cases, it can act as a barrier for germination, making the development and emergence more difficult (CARVALHO and NAKAGAWA, 2012), as verified in the present work with the 'Taquari'.
In Table 12, it is possible to verify that there was a significant difference between the treatments (seed with and without coat), with the highest emergence rate observed when the coat is removed from the seed, as expected, since a physical barrier to embryo development is eliminated, besides facilitating the process of water absorption, fundamental for germination and emergency.

A higher percentage of plants with polyembryony is observed, in Table 13, when the coat was removed from the seed $(70.37 \%)$ in comparison to the seedlings originated from seeds that germinated with the coat $(34.15 \%$ of polyembryony), a result that was also expected, since the removal of the coat/kernel provides a higher ease for embryo germination and emergence, which do not need to resist any higher physical barrier. 
Table 12. Results of the statistical analysis for the percentage of emergence of 'Taquari' seedlings, for seeds with and without coat, at the end of 12 weeks.

\begin{tabular}{lc}
\hline Treatment & \% emergence \\
\hline Seed with coat & $74.0 \mathrm{~b}$ \\
Seed without coat & \multicolumn{2}{c}{$99.4 \mathrm{a}$} \\
\hline CV & 7.28 \\
DMS & 6.13 \\
\hline
\end{tabular}

Means followed by the same letter do not differ significantly by the Tukey test at $5 \%$ probability.

Table 13. Percentage of seedlings with polyembryony in 'Taquari' tree, in seeds with and without coat.

\begin{tabular}{ll}
\hline Treatments (T) & Polyembryony (\%) \\
\hline Seed without coat & $70.37 \mathrm{a}$ \\
Seed with coat & $34.15 \mathrm{~b}$ \\
\hline F TEST & \\
Treatments & $30.254^{* *}$ \\
CV $(\%)$ & 19.03 \\
\hline
\end{tabular}

Means followed by the same letter do not differ significantly by the Tukey test at $5 \%$ probability.

Regarding the number of seedlings that emerged from each seed, around three to four were registered, for seeds with and without coat, respectively. Furthermore, it was also verified that in the seeds without coat, the maximum expression of polyembryony was reached on the fourth week after the beginning of seedling emergence, whereas for the seeds with coat, the maximum polyembryony only happened on the seventh week (Figure 2).

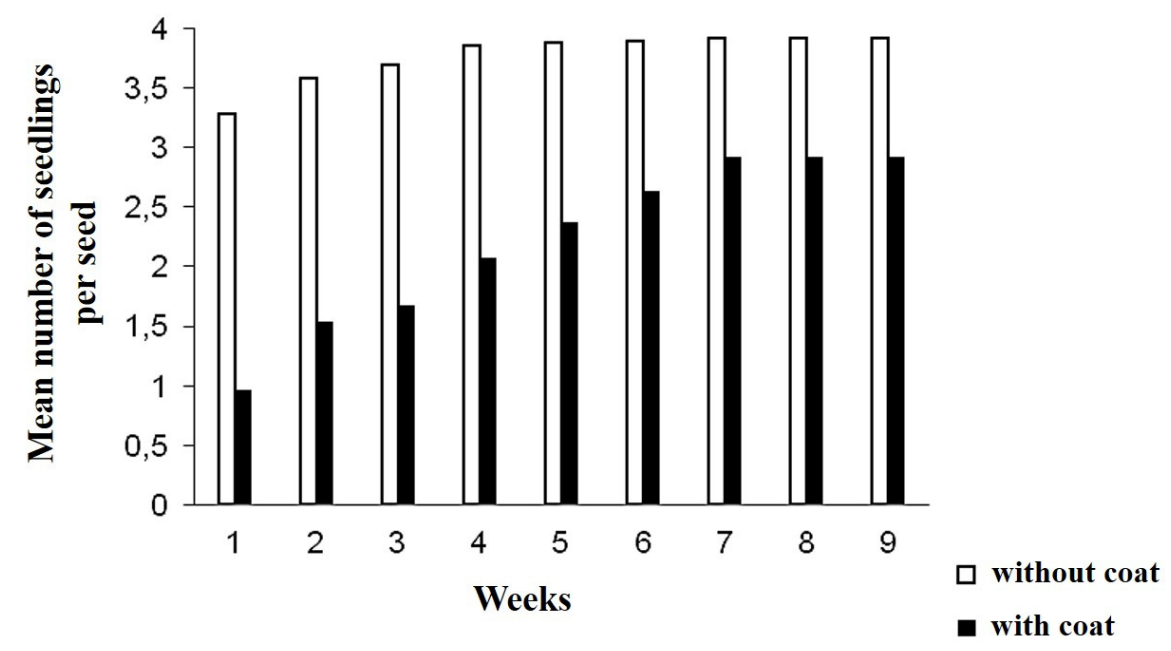

Figure 2. Mean number of seedlings emerged per seed, with and without coat, for 'Taquari'.

Similar results, for both emergence and polyembryony, were also observed in works with the rootstock cultivars 'Manguita' and 'Espada' (SANTOS et al., 2009).

\section{Quality characterization}

According to the quality characterization of the fruit (Table 14), the mean weight registered per fruit was $246.7 \mathrm{~g}$, and the firmness measured in fruit pulp was $18 \mathrm{~N}$. The evaluation of firmness in fruits is an important quality attribute because it is directly related to their shelf life, since fruit tissue softening is a consequence of their ripening (TOIVONEN; BRUMMELL, 2008). However it is important to highlight that fruit softening in postharvest depends on the softening rate at harvest, according to the Burdon et al. (2014).

For fruits peel coloration, the mean values verified for luminosity, color angle (Hue) and 
chromaticity were 50.98; 86.18 and 31.24 , respectively. The Hue angle indicates the fruit color itself, and according to the values obtained for the 'Taquari', it was concluded that the fruit presented peel coloration from red to yellow (Hue $86.18 \pm 12.1$ ). For the values detected for fruit pulp, a more yellowish pulp coloration was verified (Hue $88.76 \pm 1.8$ ) with elevated pigment saturation (Chromaticity $57.12 \pm 1.6$ ). The modification in fruit peel and pulp coloration is a consequence of the ripening of fruits, and this criterion has been used for timing harvest (Pinto et al.,2013). The mean values detected for the contents of soluble solids and titrable acidity were $18{ }^{\circ}$ Brix and $1.0 \mathrm{~g}$ citric acid $100 \mathrm{~g}^{-1}$, respectively (Table 14). These contents in the fruit can vary according to the cultivar,and are important to evaluate fruit maturation. In general during fruit maturation the soluble solids contents tend to increase, whereas titrable acidity decreases (SOUZA et al., 2011). FISCHER et al. (2009), characterizing ripe mangoes from cultivars Haden, Tommy Atkins, Palmer and Keitt, registered values between 14.88 and $18 \%$ of soluble solids, and 0.1 to $0.8 \%$ of citric acid.

The mean value obtained for fruit pulp $\mathrm{pH}$ was 3.2 (Table 14). The lower $\mathrm{pH}$ values found for most of the fruit disfavors bacterial growth; conversely, molds and yeasts are more tolerant to environments of low $\mathrm{pH}$ (CHITARRA; CHITARRA, 2005).

The mean ascorbic acid content registered in this work for the 'Taquari' fruits was $63.12 \mathrm{mg}$ of ascorbic acid $100 \mathrm{~g}^{-1}$ (Table 14), considering a high content in mangoes when compared to some varieties studied by other authors, such as in

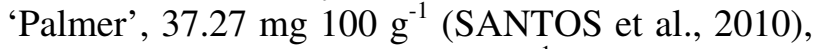
'Tommy Atkins', $13.5 \mathrm{mg} 100 \mathrm{~g}^{-1}$ (SOUZA et al., 2011) and 'Haden', 16.52 mg.100 $\mathrm{g}^{-1}$ (ALBUQUERQUE et al., 2011). The ascorbic acid is an antioxidant compound synthesized by the vegetables in amounts that vary according to, among other factors, cultivar and maturation degree, and tend to decrease with fruit ripening, because of oxidative reactions (NEVES et al., 2008).

Table 14. Physical and quality characterization of 'Taquari' harvested at the mature ripening process.

\begin{tabular}{|c|c|}
\hline \multirow{2}{*}{ Parameter } & Maturation stage \\
\hline & Mature \\
\hline Fruit weight $(\mathrm{g})$ & $986.67 \pm 70$ \\
\hline Firmness (N) & $18.04 \pm 6.4$ \\
\hline Peel luminosity & $50.98 \pm 5.5$ \\
\hline Peel Hue angle & $86.18 \pm 12.1$ \\
\hline Peel chromaticity & $31.24 \pm 4.1$ \\
\hline Pulp luminosity & $70.54 \pm 0.6$ \\
\hline Pulp Hue angle & $88.76 \pm 1.8$ \\
\hline Pulp chromaticity & $57.12 \pm 1.6$ \\
\hline Soluble solids $\left({ }^{\circ} \mathrm{Brix}\right)$ & $18 \pm 2.9$ \\
\hline Titrable acidity (g citric acid $100 \mathrm{~g}^{-1}$ ) & $1.006 \pm 0.10$ \\
\hline $\mathrm{pH}$ & $3.2 \pm 0.3$ \\
\hline Ascorbic acid (mg ascorbic acid $100 \mathrm{~g}^{-1}$ ) & $63.124 \pm 3.5$ \\
\hline $\mathrm{CO}_{2}\left(\mathrm{ml} \mathrm{CO} \mathrm{kg}^{-1} \mathrm{~h}^{-1}\right)$ & $31.10 \pm 8.3$ \\
\hline
\end{tabular}

Mean of 3 repetitions with 4 fruit each.

The mean respiratory rate of the fruit was registered as $31.10 \mathrm{ml} \mathrm{CO} \mathrm{kg}^{-1} \mathrm{~h}^{-1}$ (Table 14). The fruits classified as climacteric, such as mango, after harvested and stored under conditions of room temperature, may present a rapid increase in the respiratory rate, subsequently starting the ripening process (CHITARRA; CHITARRA, 2005). Climacteric respiration peak of 'Tommy Atkins' mangoes was reached nine days after harvest, in work completed by Alves et al. (2004). 
Nevertheless, in the present work the fruit were harvested at the mature ripening process, which means the climacteric peak occurred before harvest.

\section{CONCLUSIONS}

'Taquari' fruits presents fruit with medium size and elongated shape, resembling 'Palmer' fruits, as well as an attractive coloration of pulp and peel.
NACATA, G. et al

It is also concluded that there is a better seedling emergence in the absence of seed coat in 'Taquari' fruits, however with a higher occurrence of polyembryony.

The fruit of 'Taquari' tree present quality characteristics, such as soluble solids and titrable acidity, similar to those of the main cultivars currently commercialized in the country, but with an emphasis for the high ascorbic acid contents found in these fruit, compared to cultivars of commercial importance.

RESUMO: Os frutos da mangueira 'Taquari' têm aparência atrativa, com polpa amarelo intenso, sabor agradável e ausência de fibras, o que a torna um material com grande potencial para futuramente ser lançado como variedade. Com o objetivo de avaliar caracteres fenotípicos relativos emergência, biometria e pós-colheita, do material 'Taquari' este trabalho foi desenvolvido. Para a biometria foram utilizados 50 frutos maduros, os resultados foram avaliados por estatística descritiva, utilizando-se de medida de tendência central (média) e de variabilidade de dados (desvio-padrão). Para o teste de germinação, as sementes foram extraídas de frutos maduros e colocadas para secar, em seguida, foram colocadas para germinar em saquinhos contendo como substrato mistura de solo:areia:esterco de curral curtido (3:1:1), avaliando-se a emergência das plântulas e a poliembrionia. O delineamento foi em blocos casualizados e foram estudados 5 tratamentos, com 5 repetições cada e 10 sementes por repetição. Os dados de porcentagem foram transformados em arc-sen, submetidos à análise de variância e as médias ao teste Tukey a 5\% de probabilidade. Para a caracterização de qualidade dos frutos, utilizaram-se 12 frutos maduros, separadas em 3 lotes com 4 frutos, utilizando delineamento inteiramente casualizado. Os frutos foram caracterizados quanto a firmeza, coloração de casca e polpa, sólidos solúveis, acidez titulável, pH, ácido ascórbico e taxa respiratória. Conclui-se que a mangueira 'Taquari' apresenta frutos com características interessantes para o mercado brasileiro e há melhor emergência das plântulas na ausência do tegumento da semente, porém com maior ocorrência de poliembrionia. Para a caracterização de qualidade, os frutos apresentam parâmetros como de sólidos solúveis e acidez titulável similares às principais cultivares de mangas comercializadas no país, porém com destaque para os altos teores de ácido ascórbico encontrados.

PALAVRAS-CHAVE: Caracterização química. Mangifera indica L. Poliembrionia. Propagação.

\section{REFERENCES}

AGRIANUAL. Anuário estatístico da agricultura brasileira. São Paulo: Instituto FNP Consultoria \& Comércio, 2017. 169 p.

AlbuQuerque, E. M. B.; SANTOS, D. C.; OliveIRA, E. N. A.; AlMEIDA, F. A. C.; Silva, H. Comportamento do ácido ascórbico em manga in natura armazenada em atmosfera controlada. Revista Brasileira de Produtos Agroindustriais, v. 13, p. 263-269, 2011. https://doi.org/10.15871/15178595/rbpa.v13n3p263-269

ALVES, R. E., FILGUEIRAS, H. A. C., ALMEIDA, A. S., PEREIRA, M. E. C., COCOZZA, F. M.; JORGE, J. T. Postharvest ripening of 'Tommy Atkins' mangoes on two maturation stages treated with 1-MCP. Acta Hortic. v. 645, p. 627-632, 2004. https://doi.org/10.17660/ActaHortic.2004.645.82

AOAC. Official methods of analysis of the Association of Official Analytical Chemists International. 16. ed. Washington: Ed. Patrícia Cunniff, 1997. 850p.

BAIA, D.; ADAIME, R.; CUNHA, A. C.; SILVA, J. G. BIOMÉTRICOS DE FRUTOS DE Spondias mombin L. SOBRE OS ÍNDICES DE INFESTAÇÃO POR Anastrepha spp.(DIPTERA: TEPHRITIDAE) E PARASITISMO. Biota Amazônia, v. 5, n. 3, p. 83-87, 2015. https://doi.org/10.18561/21795746/biotaamazonia.v5n3p83-87 
BEZERRA, A. DOS E., FEITOZA, J. V. F.; CAVALCANTI, M. T. Biometria e características físico-químicas da fruta-pão (Artocarpus altilis). Revista Verde de Agroecologia e Desenvolvimento Sustentável, v. 12, n. 1, p. 100-104, 2017. https://doi.org/10.18378/rvads.v12i1.5027

BURDON, J.; PIDAKALA, P.; MARTIN, P.; MCATEE, P.A.; BOLDINGH, H.L.; HALL, A.; SCHAFFER, R.J. Postharvest performance of the yellow-fleshed 'Hort16A' kiwifruit in relation to fruit maturation. Postharvest Biology and Technology, v. 92 p. 98-106, 2014. https://doi.org/10.1016/j.postharvbio.2014.01.004

CARVALHO, N. M.; NAKAGAWA, J. Sementes: ciência, tecnologia e produção. Jaboticabal: FUNEP, 2012. 590p.

CHITARRA, M. I. F.; CHITARRA, A. B. Pós-colheita de frutas e hortaliças: fisiologia e manuseio. 2. ed. Lavras: UFLA, 2005. 783p.

COSSA, C. A.; DE LIMA, C. B.; SORACE, M. A. DA F.; JANANI, J. K.; NEGRELLE, R. R. B. LIGHT condition on the biometry and germination of dispersal units of Cordia ecalyculata. Applied Research \& Agrotechnology, v. 8, n. 2, p. 17-24, 2016.

FAO. FAOSTAT, Statistics Database. Disponível em: <http://www.fao.org/faostat/en/\#data>. Acesso em: 27 out 2017.

FISCHER, I. H.; DE ARRUDA, M. C.; DE ALMEIDA, A. M.; MONTES, S. M. N. M.; JERÔNIMO, E. M.; SIMIONATO, E. M. R. S.; DE ALMEIDA BERTANI, R. M. Postharvest diseases and physicochemical characteristics of mango. Semina: Ciências Agrárias, v. 30, n. 1, p. 107-116, 2009. https://doi.org/10.5433/1679-0359.2009v30n1p107

GUSMÃO, E.; VIEIRA, F. de A.; FONSECA JÚNIOR, É. M. da. Fruits and endocarps biometry of murici (Byrsonima verbascifolia Rich. ex A. Juss). Revista Cerne, v. 12, n. 1, p. 084-091, 2015.

HARTMANN, H. T.; KESTER, D. E. AND DAVIES JR.; F. T.; GENEVE, RL. Plant propagacion: principles and practices. 8. ed. New Jersey: Prentice Hall, 2011. 915p.

JAIME, P. C.; STOPA, S. R.; OLIVEIRA, T. P.; VIEIRA, M. L.; SZWARCWALD, C. L.; MALTA, D. C. Prevalência e distribuição sociodemográfica de marcadores de alimentação saudável, Pesquisa Nacional de Saúde, Brasil 2013. Epidemiologia e Serviços de Saúde, v. 24, n. 2, p. 267-276, 2015. https://doi.org/10.5123/S1679-49742015000200009

JUDD, W. S.; CAMPBEll C.; STEVEnS P. F.; DONOGHUE, M. J. Plant Systematics: A Phylogenetic Approach. 3 Ed. Massachusetts: Sinauer Associates Inc, 2009. 565p.

MINOLTA, Konica (2007). Precise color communication: color control from perception to instrumentation. Tokyo: Konica Minolta Sensing.

MATOS, F. dos S.; NUNES, Y. R. F.; SILVA, M. A. P.; OLIVEIRA, I. de S. Variação biométrica de diásporos de buriti (Mauritia flexuosa Lf-Arecaceae) em veredas em diferentes estágios de conservação. Ciência Florestal, v. 24, n. 4, 2014. https://doi.org/10.5902/1980509816583

NEVES, L. C.; BENEDETTE, R. M.; SILVA, V. X. D.; VIEITES, R. L.; ROBERTO, S. R. Dano de frio em limas-ácidas Tahiti, colhidas em diferentes épocas e submetidas a tratamentos térmicos e bioquímicos. Revista Brasileira de Fruticultura, v. 30, n. 2, p. 377-384, 2008. https://doi.org/10.1590/S0100-29452008000200019 PINTO, P. M.; JACOMINO, A. P.; SILVA, S. R. DA; ANDRADE, C. A. W. PONTO DE COLHEITA E MATURAÇÃO DE FRUTOS DE CAMU-CAMU COLHIDOS EM DIFERENTES ESTÁDIOS. Pesq. agropec. bras., Brasília, v. 48, n. 6, p. 605-612, 2013. 
SANTOS, J. P.; SILVA, C. V. S.; SILVA, M. A.; CARVALHO ROCHA, R. Emergência e taxa de poliembrionia em sementes de mangueira (Mangifera indica), cultivar Manguita e Espada, com e sem tegumento. Revista Verde de Agroecologia e Desenvolvimento Sustentável, v. 4, n. 4, p. 49-53, 2009.

SANTOS, L. O.; DURIGAN, J. F.; MARTINS, R. N.; MORGADO, C. M. A. Conservação e qualidade de mangas 'Palmer' submetidas a tratamento com fungicidas e hidrotérmico. Ciência e Agrotecnologia, v. 34, n. 6, p. 1514-1521, 2010. https://doi.org/10.1590/S1413-70542010000600023

SIVANKALYANI, V.; FEYGENBERG, O.; DISKIN, S.; WRIGHT, B.; ALKAN, N. Increased anthocyanin and flavonoids in mango fruit peel are associated with cold and pathogen resistance. Postharvest Biology and Technology, v. 111 p. 132-139, 2016. https://doi.org/10.1016/j.postharvbio.2015.08.001

SOUZA, M. L. D.; MORGADO, C. M. A.; MARQUES, K. M., MATTIUZ, C. F. M.; MATTIUZ, B. H. Póscolheita de mangas' Tommy Atkins' recobertas com quitosana. Revista Brasileira de Fruticultura, v. 33, n. 1, p. 337-343, 2011. https://doi.org/10.1590/S0100-29452011000500042

SOUZA, C. L. M. de; SOUZA, M. O. de; OLIVEIRA, R. S. de; NASCIMENTO, M. N.; PELACANI, C. R. Características biométricas de frutos e caracterização fisiológica de sementes de espécies de Physalis (Solanaceas). Revista Brasileira de Ciências Agrárias, v. 12, n. 3, p. 277-282, 2017.

TOIVONEN, P. M.; BRUMMELL, D. A. Biochemical bases of appearance and texture changes in fresh-cut fruit and vegetables. Postharvest Biology and Technology, v. 48, n. 1, p. 1-14, 2008. https://doi.org/10.1016/j.postharvbio.2007.09.004

VENIAL, L. R.; ALEXANDRE, R. S.; CAMATA, H.; LOPES, J. C.; ZANOTTI, R. F.; FERREIRA, A.; AGUILAR, M. A. G. Biometria e armazenamento de sementes de genótipos de cacaueiro. Pesquisa Florestal Brasileira, v. 37, n. 89, p. 39-46, 2017 https://doi.org/10.4336/2017.pfb.37.89.1239

ZUFFO, A. M.; GESTEIRA, G. D. S.; ZUFFO JÚNIOR, J. M.; ANDRADE, F. R., SOARES, I. O., ZAMBIAZZI, E. V.; GUILHERME, S. R.; SANTOS, A. S. D. Caracterização biométrica de frutos e sementes de mirindiba (Buchenavia tomentosa Eichler) e de inajá (Attalea maripa [Aubl.] Mart.) na região sul do Piauí, Brasil. Revista de Ciências Agrárias, v. 39, n. 3, p. 331-340, 2016. 